\title{
The Prospects of Radical Change Today
}

\author{
Slavoj Žižek
}

\section{http://zizek.uk/}

\begin{abstract}
In this contribution, Slavoj Žižek takes the occasion of Marx's bicentenary for reflecting on the prospects of radical change today. First, it is shown that under Stalinism, Lenin's works were quoted out of context in an arbitrary way in order to legitimise any political measure. Marxism thereby became an ideology that justified brutal subjective interventions. Second, this contribution poses the question of the revolutionary subject and democracy today. It stresses the role of both contingency and strategy in revolutions. In political assemblages taking place on public squares, the inert mass of ordinary people is transubstantiated into a politically engaged united force. The basic political problem today is how to best reconfigure democracy. Third, this contribution analyses the "interesting times" we live in. These are times that feature multiple crises, right-wing populism à la Donald Trump and Marine Le Pen, the lower classes' opposition to immigration, and the refugee crisis. Questions about human rights and their violation and about radical change need to be asked in this context.
\end{abstract}

Keywords: Karl Marx, bicentenary, radical change, Lenin, democracy, revolutionary subject, capitalism, right-wing populism, refugees, immigration, human rights, Slavoj Žižek

\section{Lenin Navigating in Uncharted Territories}

In his State and Revolution, a kind of preparatory theoretical work for the October Revolution, Lenin (1917) outlined his vision of the workers' state where every kukharka (not simply a cook, especially not a great chef, but more a modest woman-servant in the kitchen of a wealthy family) will have to learn how to rule the state, where everyone, even the highest administrators, will be paid the same worker's wages, where all administrators will be directly elected by their local constituencies which will have the right to recall them at any moment, where there will be no standing army. How this vision turned into its opposite immediately after the October Revolution is the stuff of numerous critical analyses; but what is perhaps much more interesting is the fact that Lenin proposes as the normative ground of this "utopian" vision an almost Habermasian notion of "the elementary rules of social intercourse that have been known for centuries and repeated for thousands of years in all copy-book maxims" (Lenin 1917, 467) - in Communism, this permanent normative base of human intercourse will finally rule in a non-distorted way: only in a Communist society,

"freed from capitalist slavery, from the untold horrors, savagery, absurdities, and infamies of capitalist exploitation, people will gradually become accustomed to observing the elementary rules of social intercourse that have been known for centuries and repeated for thousands of years in all copy-book maxims. They will become accustomed to observing them without force, without coercion, without subordination, without the special apparatus for coercion called the state". (Lenin 1917, 467) 
Two pages later, Lenin $(1917,469)$ again states that "we know that the fundamental social cause of excesses, which consist in the violation of the rules of social intercourse, is the exploitation of the people" - does this mean that revolution is normatively grounded in some kind of universal rules which function as eternal "human nature"? And maybe we find an echo of Lenin's preoccupation with "elementary rules of social intercourse" even in his critical remarks on Stalin's brutal manners from the last months of his life. But the reference to human nature is not Lenin's last word - in another passage of State and Revolution, he seems to claim almost the opposite: he surprisingly grounds the (in)famous difference between the lower and higher state of Communism in a different relation to human nature: in the first, lower, stage, we are still dealing with the same "human nature" as in the entire history of exploitation and class struggle, while what will happen in the second, higher, state is that "human nature" itself will be changed:

"We are not utopians, we do not 'dream' of dispensing at once with all administration, with all subordination. These anarchist dreams [...] serve only to postpone the socialist revolution until human nature has changed. No, we want the socialist revolution with people as they are now, with people who cannot dispense with subordination, control and 'foremen and accountants'. [...] A beginning can and must be made at once, overnight, to replace the specific 'bossing' of state officials by the simple functions of 'foremen and accountants', functions which are already fully within the ability of the average town dweller and can well be performed for 'workmen's wages'”. (Lenin 1917, 430; 431)

The interesting point here is that the passage from the lower to the higher stage (of Communism) does not primarily rely on the development of productive forces (beyond scarcity) but on the changing human nature. In this sense Chinese Communists (in their most radical moment) were right: there can be a Communism of poverty (if we change human nature) and a Socialism of (relative) prosperity ("goulash Communism"). When the situation is most desperate (as it was in Russia during the civil war of 1918-1920), there is always the millenarian temptation to see in this utter misery a unique chance to directly pass to Communism; Platonov's (1978) Chevengur has to be read against this background... Lenin thus seems to oscillate between a Habermasian reference to eternal natural rules of social exchange and a change in human nature itself, the rising of a New Man - in what are Lenin's oscillations and tensions grounded?

Let us turn to Jean-Claude Milner's perspicuous analysis of the imbroglios of modern European revolutions which culminated in Stalinism. Milner's starting point is the radical gap that separates exactitude (factual truth, accuracy about facts) and Truth (the Cause to which we are committed):

"When one admits the radical difference between exactitude and truth, only one ethical maxim remains: never oppose the two. Never make of the inexact the privileged means of the effects of truth. Never transform these effects into byproducts of the lie. Never make the real into an instrument of the conquest of reality. And I would allow myself to add: never make revolution into the lever of an absolute power" (Milner 2016a, 246).

To justify this claim to absolute power, the role of proverbs is significant in the Communist tradition, from Mao's "revolution is not a dinner party" to the legendary Stalinist 
"You cannot make an omelette without breaking the eggs". The preferred saying among the Yugoslav Communists was a more obscene one: "You cannot sleep with a girl without leaving some traces". But the point made is always the same: endorsing brutality with no constraints. For those for whom God (in the guise of the big Other of History whose instruments they are) exists, everything is permitted... However, theological reference can also function in the opposite way: not in the fundamentalist sense of directly legitimizing political measures as the imposition of the divine will whose instruments are revolutionaries but in the sense that the theological dimension serves as a kind of safety valve, a mark of the openness and uncertainty of the situation which prevents the political agents to conceive of their acts in the terms of self-transparency - "god" means we should always bear in mind that the outcome of our acts will never fit our expectations. This "mind the gap" does not only refer to the complexity of the situation into which we intervene; it concerns above all the utter ambiguity of the exercise of our own will.

Was this short-circuit between truth and exactitude not Stalin's basic axiom (which, of course, had to remain unspoken)? Truth is not only allowed to ignore exactitude, it is allowed to refashion it arbitrarily.

At a certain level, Stalin's break with Lenin was purely discursive, violently imposing a radically different subjective economy. The gap between general principles ("historical laws") regulating reality and pragmatic improvised decisions still palpable in Lenin is simply disavowed, and the two extremes directly coincide: on the one hand, we get total pragmatic opportunism; on the other hand, this pragmatic opportunism is legitimized by a new Marxist orthodoxy which proposes a general ontology. What this means is that Lenin himself was not a "Leninist": "Leninism" is a retroactive construction of Stalinist discourse. The key to Leninism as (Stalinist) ideology is provided by Mikhail Suslov, the member of the Politburo responsible for ideology from late Stalin's years to Gorbatchev. Alexei Yurchak (2017) pointed out how neither Khrushchev nor Brezhnev would release any document until Suslov looked it over - why?

"[I]n 1990, Fyodor Burlatsky, a former advisor to Khrushchev and Andropov, described a technique that Suslov used to manipulate Lenin's words. Suslov, who occupied the position of the Politburo's head of ideology, had an enormous library of Lenin's quotes in his Kremlin office. They were written on library cards, organized by themes, and contained in wooden file cabinets. Every time a new political campaign, economic measure, or international policy was introduced, Suslov found an appropriate quote from Lenin to support it. Once in the early 1960s, young Burlatsky showed Suslov a draft of a speech he prepared for Khrushchev. Having carefully studied the text, Suslov pointed to one place and said: 'It would be good to illustrate this idea with a quote from Vladimir Il'ich [Lenin].' When Burlatsky replied that he would find an appropriate quote, Suslov interrupted: 'No, I will do this myself.' Burlatsky writes: 'Suslov dashed to the corner of his office, pulled out one drawer and put it on the table. With his long, thin fingers he started very rapidly flipping through the cards. He pulled out one and read it. No, that's not it. Then he pulled out another one. No, still not right. Finally he took another card out and exclaimed with satisfaction, „Ok, this one will do. «'. (Burlatsky 1990, 182)

Lenin's quotes in Suslov's collection were isolated from their original contexts. Because Lenin was an extremely prolific writer who commented on all sorts of historical situations and political developments, Suslov could find appropriate quotes to legitimate as 'Leninist' almost any argument and initiative, sometimes 
even if they opposed each other. Another writer remembered that 'the very same quotes from the founders of Marxism-Leninism that Suslov successfully used under Stalin and for which Stalin so highly valued him, Suslov later employed to critique Stalin' (Tel'man 2011)" (Yurchak 2017, 173).

This was the truth of Soviet Leninism: Lenin served as the ultimate reference, a quote from his legitimized any political, economic, cultural measure, but in a totally pragmatic and arbitrary way (incidentally, exactly in the same way that the Catholic Church referred to the Bible). One should also raise the question to what extent Lenin himself sometimes referred to Marx in a similar way. In other words, the reference to Lenin posed no boundaries whatsoever: any political measure was acceptable if legitimized by a quote from Lenin. Marxism thus becomes a "world-view" allowing us the access to objective reality and its laws, and this operation brings a new false sense of security: our acts are "ontologically" covered, part of "objective reality" regulated by laws known to us, Communists. However, the price paid for this ontological security is terrible: exactitude (in the sense of truth about facts) to which Lenin was still committed disappears, facts can be voluntarily manipulated and retroactively changed, events and persons become non-events and non-persons. In other words, in Stalinism the Real of politics, brutal subjective interventions which violate the texture of reality, returns with a vengeance, although in the form of its opposite, of the respect for objective knowledge. ${ }^{1}$

Following the Stalinist turn, Communist revolutions were grounded in a clear vision of historical reality ("scientific socialism"), its laws and tendencies, so that, in spite of all its unpredictable turn, the revolution was fully located into this process of historical reality - as they liked to say: Socialism should be built in each country according to its particular conditions, but in accordance with general laws of history. In theory, revolution was thus deprived of the dimension of subjectivity proper, of radical cuts of the real into the texture of "objective reality" - in clear contrast to the French Revolution whose most radical figures perceived it as an open process lacking any support in a higher Necessity. Saint-Just wrote in 1794: "Ceux qui font des révolutions ressemblent au premier navigateur instruit par son audace. / Those who make revolutions resemble a first navigator, who has audacity alone as a guide" (de Saint-Just 2004/1794, 695).

Today, even more than in Lenin's time, we navigate in uncharted territories, where there is no global cognitive mapping. But what if this lack of clear cognitive mapping is what gives us hope that there is a way to avoid totalitarian closure (see Milner 2016b)?

\section{Elections, Popular Pressure, Inertia}

Yanis Varoufakis opens up his Adults in the Room with a report on how, on 16 April 2015, in a dark corner of a DC hotel bar, Larry Summers told him: "YYanis, you made a big mistake.' Faking steeliness, I replied, 'And what mistake was that, Larry?' 'You won the election!' came his answer" (Varoufakis 2017, 6).

In what precise sense was the electoral victory of Syriza a mistake? In accepting the electoral game, in winning at the wrong moment or...? The second round of the

\footnotetext{
${ }^{1}$ Suslov's manipulative approach strangely echoes one of the basic features of Stalin which enabled his rise to power: in the early years of his political activity, till around 1922, Stalin effectively acted as a kind of factotum of the Bolshevik party, doing (also) small bureaucratic jobs which were beneath the interest of other big Bolshevik leaders providing flats for them, etc.). Later, with his full rise to power, he gradually became more totem than fact, as they say...
} 
French presidential elections in May 2017 confronted us even more strongly with this old dilemma of the radical Left: vote or not (in the parliamentary elections)? The miserable choice le Pen / Macron exposed us to the temptation of ceasing to vote altogether, of refusing to participate in this more and more meaningless ritual. To make a decision in such situations is full of ambiguities.

The argumentation against voting subtly (or openly) oscillates between two versions, the "soft" one and the "strong" one. The "soft" version specifically targets the multiparty democracy in capitalist countries, with two main arguments: (1) media controlled by the ruling class manipulate the majority of voters and do not allow them to make rational decisions in their interest; (2) elections are a ritual that occurs every four years and its main function is to passivise voters in the long periods between the two elections. The ideal that underlies this critique is that of a non-representative "direct" democracy with continuous direct participation of the majority.

The "strong" version makes a crucial step forward and relies (explicitly or not) on a profound distrust of the majority of people: the long history of universal suffrage in the West shows that the vast majority is as a rule passive, caught in the inertia of survival, not ready to be mobilised for a Cause. That's why every radical movement is always constrained to a vanguard minority, and in order for it to gain hegemony, it has to wait patiently for a crisis (usually war) which provides a narrow window of opportunity. In such moments, an authentic vanguard can seize the day, mobilise the people (even if not the actual majority) and take over. Communists were here always utterly "nondogmatic," ready to be parasitic on another issue: land and peace (Russia), national liberation and unity against corruption (China)... They have always been well aware that mobilisation will be soon over, and have been carefully preparing the power apparatus to keep them in power at that moment (In contrast to the October Revolution that explicitly treated peasants as secondary allies, the Chinese revolution didn't even pretend to be proletarian: it directly addressed farmers as its base).

The big (defining) problem of Western Marxism was the one of the lacking revolutionary subject: how is it that the working class does not complete the passage from in-itself to for-itself and constitute itself as a revolutionary agent? This problem provided the main raison d'être of its reference to psychoanalysis, which was evoked precisely to explain the unconscious libidinal mechanisms that prevent the rise of class consciousness inscribed into the very being (social situation) of the working class. In this way, the truth of the Marxist socio-economic analysis was saved and there was no reason to give ground to the "revisionist" theories about the rise of the middle classes, etc. For this same reason, Western Marxism was also in a constant search for other social agents who could play the role of the revolutionary agent, as the under-study replacing the indisposed working class: Third World peasants, students and intellectuals, the excluded... up to the refugees.

The failure of the working class as the revolutionary subject lies already in the very core of the Bolshevik revolution: Lenin's art was to detect the "rage potential" of the disappointed peasants. The October Revolution won due to the slogan "land and peace" that was addressed to the vast peasant majority and helped seizing the short moment of their radical dissatisfaction. Lenin had been thinking along these lines already a decade earlier, which is why he was horrified at the prospect of the success of the Stolypin land reforms that aimed at creating a new strong class of independent farmers. He wrote that if Stolypin succeeded, the chance for a revolution would be lost for decades. All successful socialist revolutions, from Cuba to Yugoslavia, followed this model of seizing the opportunity in an extreme critical situation, co-opting the nationalliberation or other "rage capitals". Of course, a partisan of the logic of hegemony would 
here point out that this is the very "normal" logic of revolution, that the "critical mass" is reached precisely and only through a series of equivalences among multiple demands that is always radically contingent and dependent on a specific, unique, even set of circumstances.

A revolution never occurs when all antagonisms collapse into the big One, but when they synergetically combine their power... But the problem is more complex: the point is not just that revolution no longer rides the train of History, following its Laws, since there is no History, since history is a contingent open process; the problem is a different one: it is as if there IS a Law of History, a more or less clear predominant main line of historical development, and that revolution can only occur in its interstices, "against the current". Revolutionaries have to wait patiently for the (usually very brief) period of time when the system openly malfunctions or collapses, seize the window of opportunity, grab the power which at that moment as it were lies on the street, is up for grabs, and then fortify its hold on power, building repressive apparatuses, etc., so that, once the moment of confusion is over, the majority gets sober and is disappointed by the new regime, it is too late to get rid of it, and the revolutionaries have become firmly entrenched... Not only this, but Communists also have always carefully calculating the right moment to stop popular mobilisation.

Let's take the case of the Chinese Cultural Revolution that undoubtedly contained elements of an enacted utopia. At its very end, before the agitation was blocked by Mao himself (since he already achieved his goal of re-establishing his full power and getting rid of the top nomenklatura competition), there was the "Shanghai Commune": one million workers who simply took the official slogans seriously, demanding the abolition of the State and even the Party itself, and the direct communal organisation of society. It is significant that it was at this very point that Mao ordered the army to intervene and to restore order. The paradox is that of a leader who triggers an uncontrolled upheaval, while trying to exert full personal power - the overlapping of extreme dictatorship and extreme emancipation of the masses.

The most visible aspect of "popular presence" is thus the assemblage (in the sense of gathering of large groups in central public spaces, like the hundreds of thousands of Egyptians on Tahrir Square who forced Mubarak to resign). And an important open question is: How does cyberspace presence/pressure operate? What are its potentials? Popular presence is precisely what the term says - presence as opposed to representation, a direct pressure directed at representative organs of power; it is what defines populism in all its guises, and (as a rule, although not always) it has to rely on a charismatic leader. Examples abound: the crowd outside the Louisiana Congress that supported Huey Long and assured his victory in a key vote, crowds exerting pressure on behalf of Milošević in Serbia, crowds persisting for days in Tahrir Square during the Arab Spring or in Istanbul during protests against Erdoğan, etc.

In such a popular presence, "people themselves" make palpable their force beyond representation, but this direct presence is simultaneously people's radical self-alienation or, rather, transubstantiation in another mode of being. In a short poem written apropos the GDR workers' uprising in 1953, Brecht quotes a contemporary party functionary as saying that the people have lost the trust of the government: "Would it not be easier", Brecht slyly asks, to "dissolve the people and elect another?" (Brecht 1953). Instead of reading this poem as a case of Brecht's irony, one should take it seriously: yes, in a situation of popular mobilisation, the "people" is in a way replaced, transubstantiated - the inert mass of ordinary people is transubstantiated into a politically engaged united force. 
One should always bear in mind that the people's permanent presence equals a permanent state of exception. So what happens when people get tired, when they are no longer able to sustain the tension? Communists in power had two solutions (or, rather, two sides of one and the same solution): the party reign over the passive population and a fake popular mobilisation. Trotsky himself, the theorist of the permanent revolution, was well aware that people "cannot live for years in an uninterrupted state of high tension and intense activity" (Mandel 1995, 81), and he turned this fact into an argument for the need of the vanguard party: the self-organisation in councils cannot take over the role of the party which should run things when the people get tired. And, to amuse the people and to maintain appearances, an occasional big spectacle of pseudo-mobilisation can be of some use, from Stalinist parades up to today's North Korea. In capitalist countries there is, of course, another way to dispel popular pressure: (more or less) free elections - recently in Egypt and Turkey, but it worked also in 1968 in France. One should never forget that the agent of popular pressure is always a minority - even Occupy Wall Street was, with regard to its active participants, much closer to $1 \%$ than to $99 \%$ from its big slogan.

Should we then just ignore elections? Whatever (secret) elections are, they measure something in a purely numeric way - the percentage of the population which stands behind the main publicly presented political options. That's why Communists in power unconditionally have to stick to the form of free secret elections even if the outcome is a totally predictable $90 \%$ or more of votes (after 2 years of their reign, even the Khmer Rouge performed this ritual), or, even more, to the form of multi-party democracy, as in Poland and the GDR. And how many people are aware that even China is today a multi-party democracy with seats allotted to other "patriotic" forces apart from the Communist Party? Plus are some kind of elections not necessary to form the leading body of the ruling party itself? This was the great problem already in early Bolshevism: is it possible to have an inner-party democracy without some kind of democracy in the society outside the party? So how to keep the space open for an authentic feedback from the people outside the party circle? The problem was never that the Party nomenklatura didn't know what the people really thought - through their secret services they were always all too well informed about it.

The Chinese model is here the most consistent one: members of the de facto ruling body ( 7 members of the Standing Committee of the Political Bureau of the Communist Party of China) are elected at a Party congress every 8 years or so, and there is no debate - at the end of the congress, they are simply presented as a mysterious revelation; the selection procedure involves complex and totally opaque behind-the-screen negotiations, so that the assembled delegates who unanimously approve the list learn about it only when they vote. We are not dealing here with some kind of secondary "democratic deficit": this impenetrability is structurally necessary (within an authoritarian system, the only alternatives are a de facto monarchy as in North Korea or the traditional Communist model of a leader who simply stops ruling when he dies).

The basic problem is thus: how to move beyond multi-party democracy without falling into the trap of direct democracy? In other words: how to invent a different mode of passivity of the majority? How to cope with the unavoidable alienation of political life? This alienation has to be taken at its strongest, as the excess constitutive of the functioning of an actual power, overlooked by liberalism as well as by Leftist proponents of direct democracy. Recall the traditional liberal notion of representative power: citizens transfer (part of) their power onto the state, but under precise conditions: this power is constrained by law, limited to very precise conditions of its exercise, since the people remain the ultimate source of sovereignty and can repeal power if they decide so. In 
short, the state with its power is the minor partner in a contract which the major partner (the people) can at any point repeal or change, basically in the same way each of us can change the contractor which takes care of our waste or health... However, the moment one takes a close look at an actual state power edifice, one can easily detect an implicit but unmistakable signal: "Forget about our limitations - ultimately, we can do whatever we want with you!" This excess is not a contingent supplement spoiling the purity of power but its necessary constituent - without it, without the threat of arbitrary omnipotence, state power is not a true power, it loses its authority.

The way to undermine the spell of power is thus not to succumb to the fantasy of a transparent power; one should rather hollow out the power edifice from within by way of performing the separation between the form of power edifice and its agent (the bearer of power). As it was developed decades ago by Claude Lefort (1981), therein resides the core of the "democratic invention": in the empty place of power, i.e., the constitutive gap between the place of power and the contingent agents who, for a limited period, can occupy that place. Paradoxically, the underlying premise of democracy is thus not only that there is no political agent which has a "natural" right to power, but, much more radically, that "the people" themselves, the ultimate source of the sovereign power in democracy, doesn't exist as a substantial entity. In the Kantian way, the democratic notion of "the people" is a negative concept, a concept whose function is merely to designate a certain limit: it prohibits any determinate agent to rule with full sovereignty (The only moment when "the people exists" are the democratic elections, which are precisely the moments of the disintegration of the entire social edifice - in elections, the "people" are reduced to a mechanical collection of individuals). The claim that the people does exist is the basic axiom of "totalitarianism". And the mistake of "totalitarianism" is strictly homologous to the Kantian misuse ("paralogism") of political reason: "the People exists" through a determinate political agent which acts as if it directly embodies (not only re-presents) the People, its true Will (the totalitarian Party and its Leader), i.e., in the terms of transcendental critique, as a direct phenomenal embodiment of the noumenal People...

Critics of representative democracy endlessly vary the motif of how, for a priori formal reasons and not just on account of accidental distortions, multiparty elections betray true democracy. But while accepting this critical point, one should not only accept it as the price to be paid for any actually functioning democracy. One should even add that it is because of such a minimal "alienation" signalled by the term "representative" that a democracy functions. That is to say, what this "alienation" points towards is the "performative" character of the (democratic) choice: in such a choice, people do not vote for what (they in advance know that) they want - it is through such a choice that they realise/discover what they want. A true leader does not just follow the wishes of the majority; s/he makes the people aware of what they want.

This is why democracy retains its meaning even if the choice given is the one between very similar programmes - precisely such an empty choice makes it clear that there is no predestined bearer of power. The logical implication of this premise is Kojin Karatani's (2003) idea of combining elections with lottery in the procedure of determining who will rule us. This idea is more traditional than it may appear (he himself mentions Ancient Greece) - paradoxically, it fulfils the same task as Hegel's theory of monarchy. Karatani takes here a heroic risk at proposing a crazy-sounding definition of the difference between the dictatorship of the bourgeoisie and the dictatorship of the proletariat: "If universal suffrage by secret ballot, namely, parliamentary democracy, is the dictatorship of the bourgeoisie, the introduction of lottery should be deemed the dictatorship of the proletariat" (Karatani 2003, 183). Wasn't this also the underlying idea of 
Lenin (1917) when, in his State and Revolution, he outlined his vision of the workers' state where every kukharka (not simply a cook, especially not a great chef, but more a modest woman-servant in the kitchen of a wealthy family) will have to learn how to rule the state? From (electoral) democracy to lotocracy...

Does this mean that expertise doesn't matter? No, since another separation enters the frame here: the separation between $S_{1}$ and $S_{2}$, between Master-Signifier and expert-knowledge. The Master (people through voting) decide, make the choice, but the experts suggest to them what to choose - people want the appearance of choice, not real choice-making. This is how our democracies function - with our consent: we act as if we are free and freely deciding, silently not only accepting but even demanding that an invisible injunction (inscribed into the very form of our free speech) tells us what to do and think. As Marx knew long ago, the secret is in the form itself. In this sense, in a democracy, every ordinary citizen effectively is a king - but a king in a constitutional democracy, a king who only formally decides, whose function is to sign measures proposed by executive administration. This is why the problem of democratic rituals is homologous to the big problem of constitutional democracy: how to protect the dignity of the king? How to maintain the appearance that the king effectively decides, when we all know this is not true? What we call "crisis of democracy" does not occur when people stop believing in their own power, but, on the contrary, when they stop trusting the elites, those who are supposed to know for them and provide the guidelines, when they experience the anxiety signalling that "the (true) throne is empty", that the decision is now really theirs. There is thus in "free elections" always a minimal aspect of politeness: those in power politely pretend that they do not really hold power, and ask us to freely decide if we want to give them power - in a way which mirrors the logic of a gesture meant to be refused.

But how is this different from "totalitarian" Communism where voters are also compelled to go through the empty ritual of freely choosing (voting for) what is imposed on them? The obvious answer is that in democratic elections there is a minimal free choice, a choice that minimally matters. But a more important difference is that in "totalitarian" Communism the gap between Master-Signifier and expert knowledge disappears - how? The distance between Lenin and Stalin concerns precisely this point. So where do we stand today with regard to this dilemma?

\section{Welcome to the Boredom of Interesting Times!}

There is an old Chinese curse (about which nobody in China knows anything, so it's probably a Western invention) which says: "May you live in interesting times!" - interesting times are the times of troubles, confusion and suffering. What makes our time "interesting" is that the basic premise of classical Marxism (the premise which grounds its request for the "unity of theory and practice") is losing its pertinence. According to this premise, by its objective social position - that of the "part of no-part" (Rancière) of the social edifice, the point of its "symptomal torsion" (Badiou) -, the working class is pushed towards the correct insight into the state of society (its basic antagonism) and, simultaneously, towards the action to be taken to set it straight (the revolutionary transformation).

Does this still hold today? Does the rise of the populist fury and rage not bear witness to an irreducible break in the "unity of theory and practice"? It is as if the "objective" social position of those exploited and marginalised no longer pushes them towards a clear "cognitive mapping" of their predicament, which would engage them in a universal emancipatory struggle, but rather expresses itself in frustrated and occasionally violent impotence that betrays their loss of basic orientation. So, instead of a united 
front, local lower classes fear immigrants who take refuge in fundamentalism while the trade-unions fight for the welfare of those whom they represent, more against other parts of the working class than against the capital - can one imagine their united front? The projected unity is necessarily and continuously undermined by the counter-force that is immanent to the ongoing process of class struggle: the conflict between local lower classes and immigrants (or between feminist struggle and workers struggle) is not an externally imposed abomination caused by the manipulations of the enemy propaganda but the form of appearance of the same class struggle. Local workers perceive immigrants as the stooges of the big capital brought into their country to undermine their strength and to compete with them since their wages are lower. Immigrants see local workers, even if they are poor, as part and parcel of the Western order that marginalises. No easy preaching about how they are actually on the same side can be effective in such a situation where competition is real.

Therein resides the fatal limitation of the attempts to counter the rise of Rightist populism with Leftist populism, a populism that would listen to the real concerns of ordinary people instead of trying to impose on them some high theoretical vision of their historical task: the fears, hopes, and problems "real people" experience in their "real lives" always appear to them as moments of a certain ideological vision. As already Althusser knew, ideology is not a conceptual frame externally imposed on the wealth of reality, it is our experience of reality itself. In order to break out of ideology, it is not enough to get rid of the distorting ideological lenses - hard theoretical work is needed.

One of the most visible effects of the new backlash of racism caused by these ambiguities is the mobilisation of the obscene underside of ideology. When the black conservative Ben Carson was competing to become Republican presidential candidate, he presented his life-story as progress from a juvenile delinquent to a moral Christian. However, when journalists probed into his past, they were surprised to discover that he never had been a delinquent: he was all the time a modest well-behaved boy. But now comes the true surprise: in response to this discovery, Carson's propagandists insisted that Carson effectively WAS a delinquent in his youth. Why this weird insistence? Wouldn't it be better for Carson to appear in the eyes of his supporters (mostly white Christian conservatives) as a good boy from the beginning? No: his delinquent past perfectly fitted his image, that of the usual black boy caught in crime and other vices who found strength in hard work, discipline, and Christianity. This is what his supporters wanted to see: not simply a good black boy (as such, he would have to be recognised as one of us, fully equal to us), but somebody who first fully enjoyed being black in its transgressive aspects (sins of "lower" races always fascinated white conservatives, they were clearly an object of ambiguous envy), and then found strength to castigate his black wildness and become a moral Christian like us... Recall that Carson also claimed that slavery, deplorable as it was, helped blacks to discover and accept Christianity: the role of Christianity in this story was precisely to civilise the savage blacks by way of integrating them into white culture.

It is only against this background that we can understand how Donald Trump, a lewd and destitute person, the very opposite of Christian decency, can function as the chosen hero of the Christian conservatives. The explanation one usually hears is that, while Christian conservatives are well aware of the problematic character of Trump's personality, they have chosen to ignore this side of things since what really matters to them is Trump's political agenda, especially his anti-abortion stance. His success in making Neil Gorsuch a member of the Supreme Court could result in the overturning Roe vs. Wade, which would for Christian conservatives obliterate all his sins... But are 
things as simple as that? What if the very duality of Trump's personality - his high moral stance accompanied by personal lewdness and vulgarities - is what makes him attractive to Christian conservatives? What if they secretly identify with this very duality? Exactly the same goes for Poland's current de facto ruler Jarosław Kaczyński who, in a 1997 interview for Gazeta Wyborcza, inelegantly exclaimed, "It's our fucking turn" (Teraz kurwa my). This phrase (which then became a classic locus in Polish politics) can be vaguely translated as "It's our fucking time, now we are in power, it's our term", but its literal meaning is more vulgar, something like "now it's our time to fuck the whore" (after waiting in line in a brothel) (see Sierakowski 2017). It's important that this phrase was publicly uttered by a devout Catholic conservative, protector of Christian morality: it's the hidden obverse which effectively sustains Catholic "moral" politics.

The Communist side is also not far behind in similar vulgarities. For example, in his speech at the Lushan party conference in July 1959, when the first reports made it clear what a fiasco the Great Leap Forward was, Mao called the party cadre to assume their part of responsibility, and he concluded the speech with admitting that his own responsibility, especially for the unfortunate campaign to make steel in every village, is the greatest - here are the last lines of the speech:

"The chaos caused was on a grand scale and I take responsibility. Comrades, you must all analyze your own responsibility. If you have to shit, shit! If you have to fart, fart! You will feel much better for it." (Mao 1959)

Why this vulgar metaphor? In what sense can the self-critical admission of one's responsibility for serious mistakes be compared to the need to shit and fart? I presume the solution is that, for Mao, to take responsibility does not mean so much an expression of remorse which may even push me to offer to step down; it's more that, by doing it, you get rid of responsibility, so that no wonder you "feel much better for it" like after a good shit - you don't admit you are shit, you get rid of the shit in you... this is what the Stalinist "self-criticism" effectively amounts to.

The important lesson here is that this coming-open of the obscene background of our ideological space (to put its somewhat simply: the fact that we can now more and more openly make - racist, sexist... - statements which, till recently, belonged to private space) in no way means that the time of mystification is over, that now ideology openly displays its cards. On the contrary, when obscenity penetrates the scene itself, ideological mystification is at its strongest: the true political, economic and ideological stakes are more invisible than ever. In short, the public obscenity is always sustained by a concealed moralism, its practitioners secretly believe they are fighting for a cause, and it is at this level that they should be attacked.

The problem is not that Trump is a clown. The problem is that there is a programme behind his provocations, a method in his madness. Trump's (and others') vulgar obscenities are part of their populist strategy to sell this programme to ordinary people, a programme which (in the long term, at least) works against ordinary people: lower taxes for the rich, less healthcare and workers' protection, etc. Unfortunately, people are ready to swallow many things if they are presented to them through laughter.

On May 182017 I had a conversation with Will Self at Emmanuel Centre in London (Žižek and Self 2017). Its most memorable moment (for me, at least) occurred when Self - while broadly agreeing with me that, if things will go on the way they do now, our societies are doomed, and an unthinkable catastrophe lies ahead - reproached me for still counting on some big "revolutionary" act that will turn the (global) tide and prevent this sliding towards catastrophe. His main reason was that, with our way of life, we are 
so deeply immersed into the process of (not only ecological) self-destruction that no awareness of what we are doing can stop us doing it. Self then asked the public how many of them have smart phones, reminding them that each phone needs coltan, a precious metal from Congo where it is mined by de facto slave labour in a way detrimental to the environment. So what can we do, after we admit we are all co-responsible and unable to actively intervene? Self's answer: nothing big, just pay taxes (to enable the state to maintain minimal order of law and welfare) and enjoy your isolated life, yanking... My reply (which I failed to articulate properly there) is that such a cynicalhedonist stance fits perfectly those in power, that it is ideology at its purest: any collective counter-act is in advance devalued ("Who are you to protest? Are you not also using coltan? So what right do you have to put the blame on big corporations?"), so all we can do is remain private citizens who masochistically enjoy their guilt and withdraw in private pleasures...

The latest Italian electoral results as well as the difficulty of forming a new coalition in Germany merely confirm the disappearance of the modest Social-Democratic Left and the rise of the new populism as the only (fake) alternative to global capitalism. This state of things does not mean that we are lost. It rather points in the direction of the lines from Joel 3:14 - "Multitudes, multitudes, in the valley of decision! For the day of the Lord is near in the valley of decision." - that provide the first accurate description of the moment when a society is at a crossroads, confronted with a choice that may decide its fate.

This is the situation of Europe today. Every anti-immigrant populist would fully agree with this claim: yes, Europe's very identity is threatened by the invasion of Muslim and other refugee multitudes. But the actual situation is exactly the opposite: it is today's anti-immigrant populists who are the true threat to the emancipatory core of the European Enlightenment. A Europe where Marine le Pen or Geert Wilders are in power is no longer Europe. So what is this Europe worth fighting for?

The true novelty of the French Revolution resides in the distinction between citizens' rights and human rights. One should reject here the classic Marxist notion of human rights as the rights of the member of bourgeois civil society. While citizens are defined by the political order of a sovereign state, "human" is what remains of a citizen when he/she is deprived of the citizenship, finding him/herself in what in an artillery one calls the open space, reduced to the abstract talking body. Recall the Calais camp before it was dismantled - as Jean-Claude Milner (2016a, 259) wrote, "those who are assembled there from 2000 are not guilty of anything, they are not accused of anything, they do not infringe upon any part of the law; they are simply there and they live". It is in this sense that the universal human rights should remain our regulative when we negotiate the difficult relationship between the constraints of citizenship and particular ways of life. Without this compass we inevitably regress to barbarism.

In his reading of the (in)famous difference between human rights and citizens' rights, Milner (2016a) rejects the Marxist critical notion of human rights as the rights of the member of the bourgeois civil society: for Milner, the citizen is the member of a community, sharing its specific culture, while a human being is what remains of a citizen when s/he is deprived of his/her citizenship - human rights are "natural" rights only in this sense of the externality to a particular culture, they have nothing to do with eternal nature since they apply to what remains of a citizen after s/he is subtracted from a specific polis. In this sense, their "nature" is a retroactive effect of culture, it applies to a human being reduced to the zero level of a speaking body: 
"[...] one gains a glimpse into the real of the rights of the body in examining what goes on when they are denied to individuals. Every day brings us a new example. I do not have to think about bombs and poisonous gasses, I think about Calais: those who are assembled there from 2000 are not guilty of anything, they are not accused of anything, they do not infringe upon any part of the law; they are simply there and they live; the proof that they live is that sometimes they die. Nobody knows what languages they are speaking and anyway one doesn't listen to them. One only knows that they speak. They are therefore reduced to the status of speaking bodies; by the settlement to which they are submitted they literally render visible in a negative way the real of the rights of man/woman. [...] These rights are openly distinguished from the rights of a citizen since refugees are precisely not the citizens of Calais and mostly do not want to become that." (Milner 2016a, 259).

Milner (2016a, 260-261) insists on the "vulgar" materiality of these rights: they are more basic than the rights to reunion, free speech, opinion, etc. Before that comes the material base of a body: water, food, hygiene, minimal space of privacy. If individuals are deprived of this, their "higher" human rights disappear. Human rights are first such basic material rights: toilets, kitchen, healthcare. Rights begin with the space for secretion - this the sad base of my story about the different shape of European toilets (Žižek 1997, 3-4). Insofar as human rights (as distinct from the citizens' rights) were first proclaimed in the French Revolution, one should note the irony of the fact that Calais is a French city.

Here, of course, we enter a double game: Marxists emphasise "material" rights against freedom of opinion and the press, etc. (but fail to deliver them when in power), while "bourgeois democracies" emphasise other freedoms. The lesson here is that universal human rights are - in their very universality - historically produced and specified; their exact extent and content is a matter of socio-political struggles. Is already Milner's renaming them "the rights of man/woman" not the effect of contemporary feminist struggles? And we should bear in mind that although humans who are covered by these rights are "proletarian" in the sense of being deprived of citizenship, they are nonetheless not abstract Cartesian cogitos - they come as individuals embedded in a specific way of life often in conflict with the way of life of the country in which they dwell as refugees.

So we have to take into account here three levels: the abstract universality of a human being qua bearer of human rights, the particularity of a specific way of life to which an individual belongs, and the singularity of citizenship as the mediating moment between the two extremes (as a citizen, I am universal, but universal as belonging to the singularity of a state). The interaction of these three levels cannot but engender multiple difficulties - suffice it to recall the vagaries of power that plague contemporary attempts to enact radical emancipation.

\section{References}

Brecht, Bertolt. 1953. The Solution. Monthly Review Online, https://mronline.org/2006/08/14/brecht140806-html/

Burlatsky, Fyodor. 1990. Vozhdi i sovetniki: o Khrushcheve, Andropove i ne tol'ko o nikh. Moscow: Politizdat.

de Saint-Just, Louis Antoine. 2004/1794. Rapport sur les factions de l'étranger. In CEuvres completes. Paris: Gallimard.

Karatani, Kojin. 2003. Transcritique. On Kant and Marx. Cambridge, MA: The MIT Press. 
Lefort, Claude. 1981. L'invention démocratique: les limites de la domination totalitaire. Paris: Fayard.

Lenin, Vladimir I. 1917. The State and Revolution. The Marxist Theory of the State and the Tasks of the Proletariat in the Revolution. In Lenin Collected Works Volume 25, 385-497. Moscow: Progress.

Mandel, Ernest. 1995. Trotsky as Alternative. London: Verso.

Mao, Tse-tung. 1959. Speech at the Lushan Conference. July 23, 1959. https://www.marxists.org/reference/archive/mao/selected-works/volume-8/mswv8 34.htm

Milner, Jean-Claude. 2016a. Relire la Revolution. Lagrasse: Verdier.

Milner, Jean-Claude. 2016b. The Prince and the Revolutionary. Crisis \& Critique 3 (1): 70-78.

Platonov, Andrei. 1978. Chevengur. Ann Arbor, Ml: Ardis.

Sierakowski, Sławomir. 2017. Europe's New Appeasers. Project Syndicate, June 9, 2017. https://www.project-syndicate.org/commentary/poland-hungary-authoritarian-appeasement-by-slawomir-sierakowski-2017-06

Tel'man, Iosif. 2011. Chelovek v galoshakh. Ezhenedel'nik "Sekret," October 21. http://velelens.livejournal.com/814854.html

Varoufakis, Yanis. 2017. Adults in the Room. London: Penguin.

Yurchak, Alexei. 2017. The Canon and the Mushroom. Lenin, Sacredness, and Soviet Collapse. HAU: Journal of Ethnographic Theory 7 (2): 165-198.

Žižek, Slavoj. 1997. The Plague of Fantasies. London: Verso.

Žižek, Slavoj and Will Self. 2017. Conversation. Recorded on May 18, 2017. Emmanuel Centre, London. https://www.youtube.com/watch?v=Cld1iOWQUuo

\section{About the Author}

Slavoj Žižek

is a leading philosopher and cultural critic. He is a professor in the Department of Philosophy at the University of Ljubljana, Global Distinguished Professor at New York University, and International Director of the Birkbeck Institute for the Humanities at the University of London. $\mathrm{He}$ is the author of more than forty books, including Reading Marx (2018, together with Frank Ruda and Agon Hamza), Incontinence of the Void: Economico-Philosophical Spandrels (2017), The Courage of Hopelessness: Chronicles of a Year of Acting Dangerously (2017), Against the Double Blackmail (2016), Disparities (2016), Absolute Recoil: Towards a New Foundation of Dialectical Materialism (2014), Less than Nothing: Hegel and the Shadow of Dialectical Materialism (2012), The Year of Dreaming Dangerously (2012), Living in the End Times (2010), First as Tragedy, then as Farce (2009), and In Defense of Lost Causes (2008). http://zizek.uk/ 